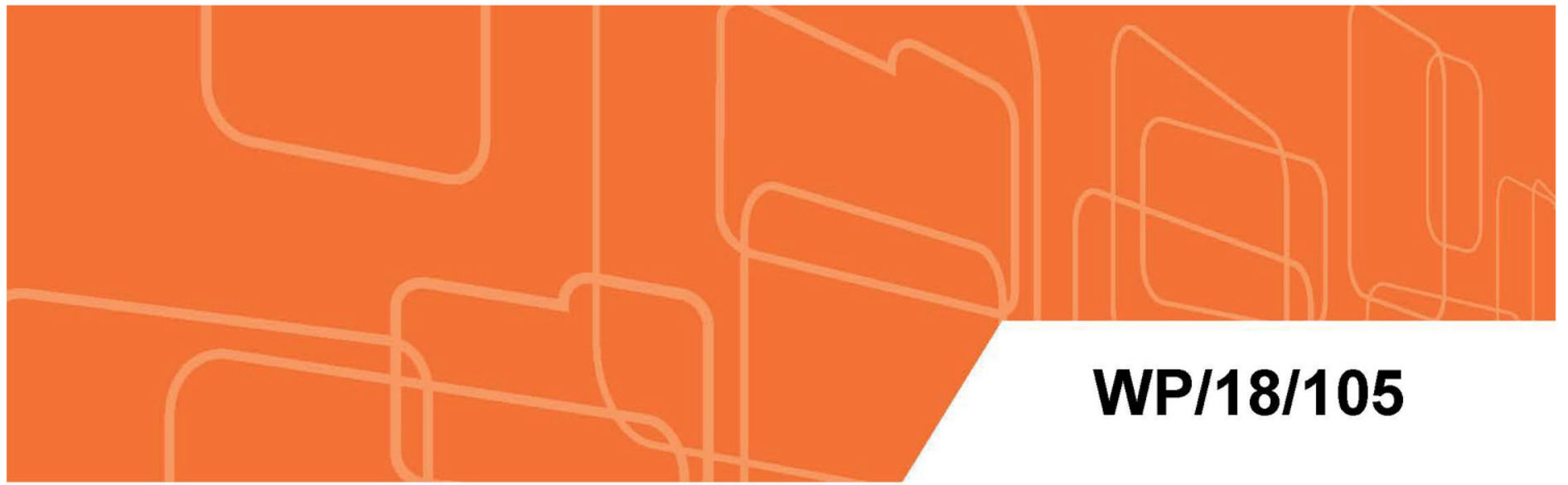

IMF Working Paper

\title{
Gender Equality: Which Policies Have the Biggest Bang for the Buck?
}

by Sonali Jain-Chandra, Kalpana Kochhar, Monique Newiak, Yang Yang, and Edda Zoli

IMF Working Papers describe research in progress by the author(s) and are published to elicit comments and to encourage debate. The views expressed in IMF Working Papers are those of the author(s) and do not necessarily represent the views of the IMF, its

Executive Board, or IMF management. 


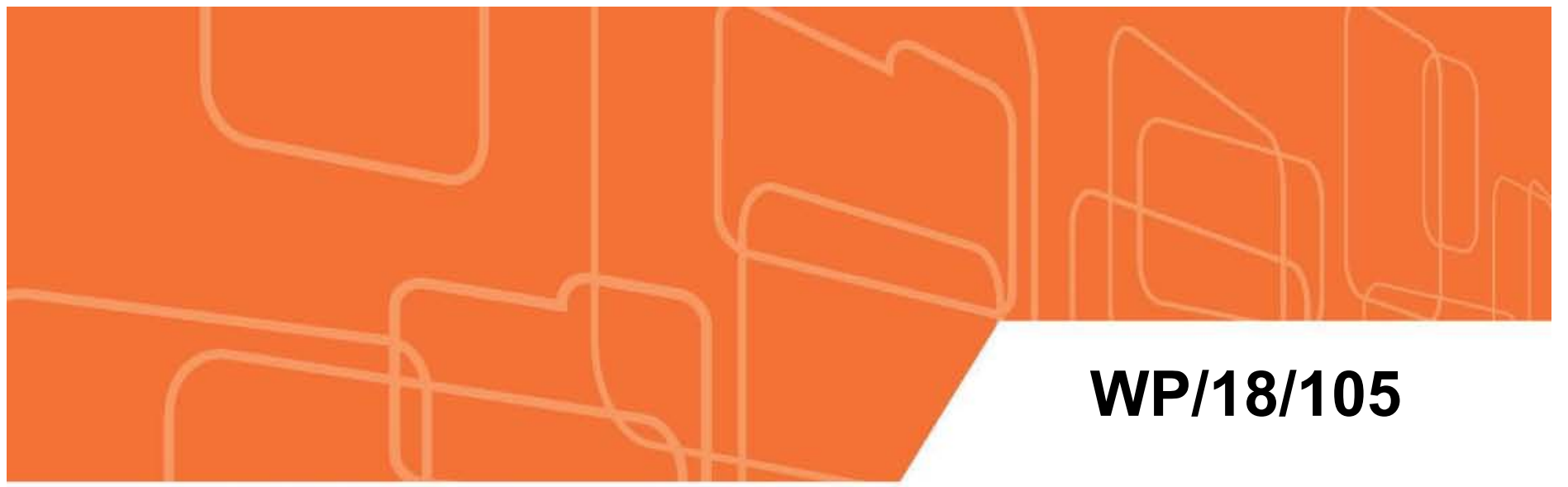

\section{IMF Working Paper}

\section{Gender Equality: Which Policies Have the Biggest Bang for the Buck?}

by Sonali Jain-Chandra, Kalpana Kochhar, Monique Newiak, Yang Yang, and Edda Zoli

IMF Working Papers describe research in progress by the author(s) and are published to elicit comments and to encourage debate. The views expressed in IMF Working Papers are those of the author(s) and do not necessarily represent the views of the IMF, its Executive Board, or IMF management. 


\title{
IMF Working Paper
}

African Department, Asia and Pacific Department, Human Resources Department, and Strategy, Policy and Review Department

\section{Gender Equality: Which Policies Have the Biggest Bang for the Buck? \\ Prepared by Sonali Jain-Chandra, Kalpana Kochhar, Monique Newiak, Yang Yang and Edda Zoli}

Authorized for distribution by Kalpana Kochhar

May 2018

IMF Working Papers describe research in progress by the author(s) and are published to elicit comments and to encourage debate. The views expressed in IMF Working Papers are those of the author(s) and do not necessarily represent the views of the IMF, its Executive Board, or IMF management.

\begin{abstract}
This paper analyzes the relationship between fiscal and structural policies and gender inequality in education and labor force participation for countries at different stages of development. Due to the substantial number of possible factors that link with gender inequality previously highlighted in the literature, we pay particular attention to addressing model uncertainty and using various statistical methods to find the variables with the strongest links to gender gaps. We find that higher public spending on education, better sanitation facilities, low adolescent fertility, and narrower marriage age gaps are significantly related to narrower gender gaps in education. We also find that better infrastructure, a stronger institutional environment, more equal legal rights, and low adolescent fertility rates are strongly associated with higher female labor force participation. When labor market protection is low, an increase in protection is associated with a narrowing of labor force participation gaps between men and women. But when labor market protection levels are high, an increase in protection is associated with a widening in labor force participation gaps.
\end{abstract}

JEL Classification Numbers: J2, J16, H5, I24

Keywords: gender gap, female labor force participation

Author's E-Mail Address: SJainchandra@imf.org, KKochhar@,imf.org, MNewiak@imf.org, YYang5@imf.org, EZoli@,imf.org 


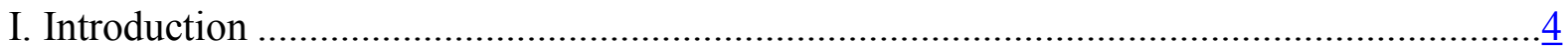

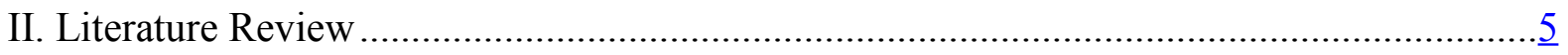

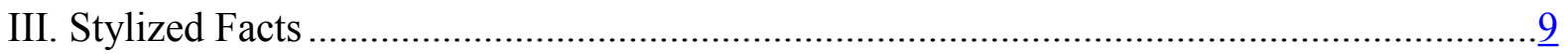

IV. Determinants of Gender Inequality_Frequentist Approach.....................................12

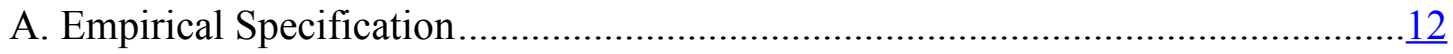

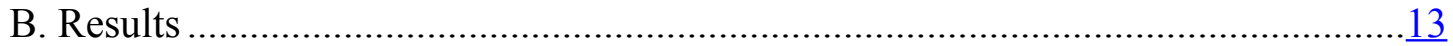

V. Identifying Robust Determinants of Gender Inequality - Application of the Bayesian

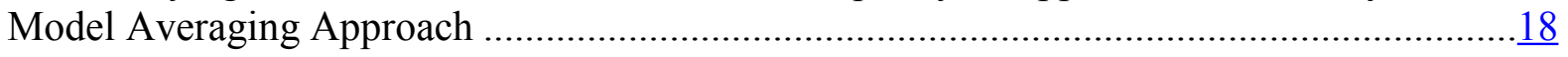

VI. Quantifying the Effect of Policies Across Regions ................................................21

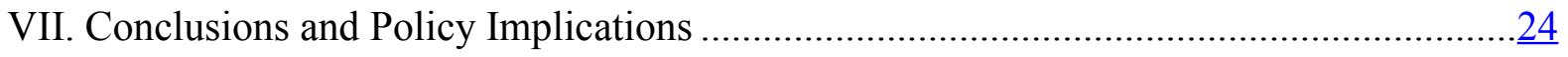

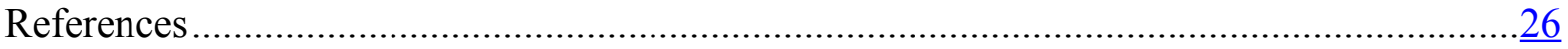

Tables

1. Determinants of the Gender Gap in Education ...........................................................14

2. Determinants of the Gender Gap in Labor Force Participation ....................................... 17

3. Labor Market Protection and Labor Force Participation by Men and Women ...................18

4. Gender Gap in Education: A BMA Exercise: BMA Results ........................................20

5. Determinant of Gender Gap in Labor Force Participation: BMA Results..........................21

Figures

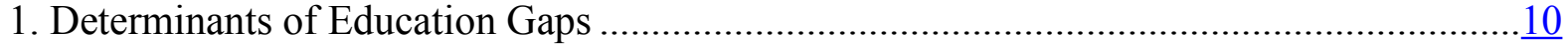

2. Determinants of Labor Force Participation Gaps ....................................................... 11

3. Quantifying the Drivers of Labor Force Participation Gaps across Regions......................22

4. Quantifying the Impact of Policies on the Gender Gap in Labor Force Participation across

Regions

Annexes

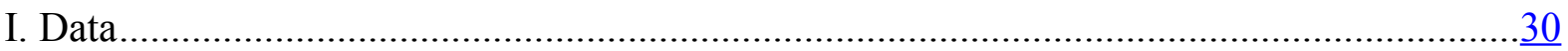

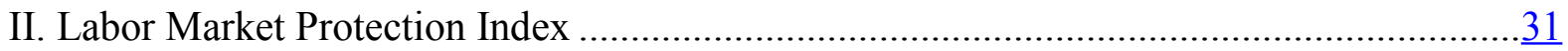




\section{INTRODUCTION}

1. Despite progress of the recent decades, gender gaps in various areas of economic opportunities and outcomes remain, with significant macroeconomic consequences. Female labor force participation is lower than male participation in most countries, women's access to education is more limited than that of men, and gender gaps in accessing social and financial services and legal rights persist, especially in emerging markets and low-income countries. These disparities have adverse implications for women's economic productivity, income equality, and, ultimately, growth and economic development (Duflo 2012; Jayachandran 2015; Kochhar, Jain-Chandra and Newiak, 2017). Indeed, vast empirical evidence exists to show that significant macroeconomic gains can be realized when women are able to develop their full labor market potential (Elborgh-Woytek and others 2013, Cuberes and Teignier 2016; Kochhar, Jain-Chandra and Newiak, 2017).

\section{What can policymakers do, then, to promote gender equality in economic} empowerment? Which policies are more effective in fostering female labor force participation and women's access to education? Building on evidence from numerous microeconomic and macroeconomic studies, this paper conducts an empirical analysis based on macroeconomic data to estimate the impact of fiscal and structural policies on gender inequality in a sample of 100 countries from 1980 to 2014. Our study focuses in particular on policies that could address gender gaps in labor force participation and educational opportunities for women, as measured by years of schooling and years in tertiary education. Realizing that there is no silver-bullet for policies to take effect across all income levels, we also examine whether certain policies are more critical in emerging markets and low-income countries (LICs) than in advanced economies.

\section{The novelty of our paper is that it applies Bayesian Model Averaging (BMA) to} identify the most fundamental and robust factors that link to gender inequality. Against the background of the large number of potential determinants of gender inequality suggested in the literature, this methodology helps address model uncertainty as part of the statistical methodology (Fernandez and others 2001; Sala-i-Martin 2004; Papageorgiou and Masanjala 2008). BMA is well established in the growth literature to address the complications posed by the fact that a vast number of determinants have been proposed to explain real GDP per capita growth (for instance, Durlauf and others (2004) surveyed 140 determinants of economic growth). Bayesian model averaging has also been used to introduce new development determinants into the literature (Eicher and Newiak 2013). While the number of suggested drivers of gender equality in the literature is large, no other paper has yet addressed model uncertainty to the best of our knowledge.

4. We find that the scope for policies to narrow gender gaps is substantial and we identify policy actions that are likely to provide the largest "bang for the buck" in reducing various dimensions of gender inequality. The results of our paper should be read 
as robust associations between gender equality and certain factors, rather than necessarily as causal relationships.

- Policies to narrow gender gaps in education. Good sanitation facilities, as highlighted in UNESCO (2014), are strongly associated with a narrower education gap between males and females in emerging markets and low-income economies. This findingalready emphasized in case studies and other micro level analysis (e.g., Hannan and Anderson 2002: Adukia 2016) - is here confirmed with macro data. Low adolescent fertility, a narrower marriage age gap (to proxy cultural norms and under-age marriage) and public spending on education are also linked to lower gender gaps in education.

- Policies to narrow gender gaps in labor force participation. Improvements in infrastructure (such as electricity, better access to water, and improved sanitation facilities), stronger legal rights for females, low adolescent fertility, a narrower marriage age gap and a stronger institutional environment (as measured by the corruption index) strongly relate to higher female labor force participation and narrower gender gaps in labor force participation. This paper also finds that labor market protection appears to have a non-linear relationship labor market participation gaps. At lower levels of labor market protection, stronger protection is associated with narrower labor force participation gaps, but at higher levels of protection, excessive labor market rigidity diminishes that effect. This result is broadly consistent with World Bank (2013) which finds that tighter "employment protection legislation and minimum wage can shift employment away from young people, women, the less skilled". But there exists a "plateau" for labor market protection at which changes in employment protection have minimal effect on employment (and productivity). According to this study, when the edge of employment protection is too-strict or the too-loose, impacts are more negative.

5. The paper is organized as follows. Section II reviews the existing literature; Section III presents stylized facts on the relationship between macroeconomic and structural policies, and gender gaps in advanced economies, emerging markets and LICs. The data, empirical methodology, and estimation results using OLS are discussed in section IV, while Section V presents the results of the BMA approach. Section VI discusses the conclusions and policy implications.

\section{Literature REVIEW}

\section{Gender equality encompasses a variety of dimensions, such as equality in the} access to education, health and financial access for women and men, equality in labor force participation, and political representation. When analyzing the impact of policies on gender equality, the cross-country literature often focuses on labor market outcomes, namely, female labor force participation or employment, while studies at the country level have also more deeply analyzed how policies impact inequality of opportunity, such as school enrollment rates. For each outcome variable, previous papers have explored many potential determinants of gender gaps. Micro-level studies — both theoretical and empirical — are particularly insightful in this respect, and provide the underpinnings to the analysis of this 
paper. The main areas of work in the theoretical and empirical literature-both at the micro and macro level and covering cross-country and panel-studies - are summarized below. Since this literature is vast, this overview does not aim to be exhaustive. Our paper presents a systematic approach to looking into the significance of factors previously identified in the literature.

\section{A number of studies have pointed to the theoretical underpinning of female} labor supply. Female labor supply is often modeled using the framework of the time allocation model (Becker 1965), which posits that women make their labor supply decisions not only considering leisure and labor, but also home-based production of goods and services (including caring for children). Working for a wage is chosen only if earnings at least make up for the lost home production (and the associated costs), implying a higher elasticity of female labor supply to wages. Many studies have emphasized the importance of education in models of female labor supply. Using micro data, Eckstein and Lifshitz (2011) estimate a dynamic stochastic female labor supply model with discrete choice (contained in Eckstein and Wolpin 1989) and find that changes in education and wages play a large role in explaining female employment, with the former accounting for a third of the increase in female employment, and the latter explaining about 20 percent. They also formulate a new framework that models intra-family dynamics (using dynamic stochastic games) and relate it to the household's labor supply decision. Fernandez and Wong (2014) develop a dynamic life-cycle model with incomplete markets and risk-averse agents who differ in their educational endowments and make work, consumption, and savings decisions. They find that, in addition to the above factors, divorce risk has a large impact on married women's participation rates.

\section{Empirical work has shown that fertility and higher marriage rates significantly} affect female labor force participation. For individual countries, there is evidence of a negative relationship between fertility and women's participation in the labor force. For instance, in a panel of 97 countries, Bloom and others (2009) find that the number of births is significantly negatively related to women's labor supply, with each birth on average decreasing women's labor supply by almost two years during a women's reproductive life. Mishra and Smyth (2010) estimate that a 1 percent increase in the fertility rate results in a 0.4 percent decrease in female labor force participation rates in G7 countries. While there is a negative relationship between the variables at the individual country level, there is a positive relationship between fertility and female labor force participation at the cross-country level. Using data from OECD economies, De Laat and Sevilla-Sanz (2011) explain this puzzling result by taking into account men's contribution to home production. They find that women living in countries where men participate more in-home production are better able to combine motherhood with work outside the house, leading to greater participation in the labor force at relatively high fertility levels. The trade-off between family and work is also reflected in a negative correlation between female labor force participation and marriage rates. Luo (2018) exploits exogenous variation in the US marriage market caused by World 
War II casualties to show that marriage is an important opportunity cost that hinders women from becoming entrepreneurs.

\section{Fiscal policies that are tailored to country-circumstances can significantly} increase female labor force participation (Aguirre and others 2012; Duflo 2012; Revenga and Shetty 2012; Sen 2001; Thévenon 2013; Kalb 2009). On the revenue side, tax credits or benefits for low-wage earners can stimulate labor force participation, including among women. By reducing the net tax liability or even turning it negative, tax credits increase the net income gain from accepting a job. Such credits are usually phased out as income rises. Policies can also build on the fact that female labor supply is more responsive to taxes than male labor supply. For example, a switch from family income taxation to individual income taxation that reduces the tax burden for (predominantly female) secondary earners can support female labor force participation, while it would affect the less-tax-elastic male labor supply to a smaller extent (Elborgh-Woytek and others 2013).

10. As for expenditure policy, higher spending on infrastructure and education, as well as better access to comprehensive, affordable, and high-quality child care supports female employment (Gong, Breunig, and King 2010). The elasticity of female labor supply with respect to the price of child care has been estimated to range from -0.13 to -0.2 . Thus, reducing the price of childcare by 50 percent could be associated with an increase of 6.5 to 10 percent in the labor supply of young mothers. Other studies document the importance of public infrastructure to boost the participation of women in the labor force. Norando (2010) finds that a large part of the difference in female labor force participation rates in 1990 between the United States, on the one hand, and Brazil and Mexico, on the other, can be explained by the availability of basic infrastructure (electricity and running water). Ghani, Kerr, and O'Connell (2013) note that inadequate infrastructure affects women's participation more than that of men because women are more often responsible for household activities. Using micro data, Das et al. (2015) estimate that female labor force participation in India would rise by 2 percentage points if Indian states increased education spending by 1 percent of GDP.

\section{Gender-based legal restrictions impede women's empowerment and thus their} economic participation. Gonzales and others (2015) examine the effect of gender-based legal restrictions and other policy choices and demographic characteristics on female labor force participation. Drawing on a large panel data set of gender-related legal restrictions (World Bank 2013), they find that restrictions on women's rights to inheritance and property, as well as legal impediments to undertaking economic activities such as opening a bank account or freely pursuing a profession, are strongly associated with larger gender gaps in labor force participation.

\section{Female labor force participation is positively correlated with educational}

attainment for women. Calibrating a dynamic model of labor supply, Eckstein and Lifshitz (2011) find that one-third of the increase in female employment during the last century in the 
United States can be attributed to education. In an empirical exercise, Steinberg and Nakane (2012), show that a one standard deviation increase in the education level in Organization for Economic Cooperation and Development (OECD) countries is associated with a 3 percentage points increase in female labor force participation.

\section{A lower female age at marriage and large age gaps between men and women at} marriage have been associated with high gender inequality. Marrying at a younger age is associated with becoming a parent at a younger age and thus impacts an individuals' educational investment decision. For instance, using micro data from rural Bangladesh, Field and Ambrus (2008) show that each additional year that marriage is delayed is associated with about one--fifth additional year of schooling and 5.6 percent higher literacy for women. Arguing that a lower age of marriage for women may simply reflect lower marriage ages for both men and women in a society, Stimple and Stadelmann (2016) test the relationship between the gap between men and women at marriage and estimate that an additional age difference between husband and wife of one year reduces female secondary schooling completion rates by 14 percentage points. This, in turn, adversely impacts female education more than male education, therefore increasing the education gap.

\section{In this paper, we construct a large country-year panel dataset to examine the} determinants of gender gaps in a systematic way. As noted in the literature survey above, many variables have been proposed in both macroeconomic and microeconomic studies as potential determinants of gender gaps. The large number of potential determinants creates complications in several aspects.

- First, a large number of regressors makes it hard to identify the variables that are the most strongly related to gender gaps. Given that the sample size is often a constraint in macrolevel studies, large model uncertainty caused by many potential regressors becomes an obstacle for researchers to draw conclusions on the importance of regressors.

- Second, from a more practical perspective, policy advice demands prioritization.

Resources and capacity are often constrained, and policies that pay the best bang for the buck should be prioritized. To tackle model uncertainty, we use Bayesian Model Averaging ${ }^{1}$ to identify the most robust determinants of gender gaps. Sala-i-Martin et al. (2004) pioneered the use of BMA in the growth regression literature. In many of the recent empirical macroeconomic studies, BMA has been commonly used as a mean to address model uncertainty. ${ }^{2} \mathrm{We}$ contribute to the literature by being the first to apply BMA to study the determinants of gender inequality.

\footnotetext{
${ }^{1}$ Leamer (1978) discusses the use of Bayesian methods to select econometric models. Raftery et al. (1997) introduces the Bayesian Model Averaging as an alternative approach to hypothesis testing and model selection in social sciences. Please refer to Section V. of this paper for a more detailed discussion of BMA.

${ }^{2}$ See, for example, Jones and Schneider (2006), Moral-Benito (2012), and Du et al. (2013).
} 


\section{STYlized FACTS}

15. Before turning to the empirical investigation, we take a preliminary look at the data on our sample of 100 countries from 1980 to 2014, to uncover possible correlations among policy variables and gender inequality in education and labor force participation, as well as highlight any differences between developing countries, emerging markets and advanced countries. ${ }^{3}$ As shown in Annex Table A1, some of the gaps may be small when considering the global sample. However, disaggregating advanced economies from emerging and developing countries shows that the size of gender gaps varies among different country groups (e.g., while education gaps are closed in advanced markets, they persist in EMDEs).

\section{Stylized facts point to a number of possible determinants of gender gaps in education:}

- Higher public spending on education is associated with a narrower gender gap in years of schooling in both developed and developing countries, although the relationship appears to be stronger in the latter (Figure 1, panel 1), possibly reflecting larger marginal returns to education when the level of economic development is lower.

- Better infrastructure, as measured by improved access to sanitation facilities, is negatively correlated with the gender gap in years of schooling in emerging markets (Figure 1, panel 2). This may be because in countries with better infrastructure, females can reduce the time spent on household activities, and increase the time in school. In most societies, females are responsible for household water supply and sanitation. This activity can be very time-consuming in areas lacking adequate access to water and infrastructure. For example, collecting water is estimated to take as much as 26 percent of women's time in rural Africa (Lamb 2015). Also, access to sanitation may have a direct impact by allowing adolescent girls to attend school more regularly and reduce security concerns. This effect is not evident in advanced economies, where access to sanitation facilities is high and is not likely to be a binding constraint.

- Finally, the data suggest that improved access to finance is associated with a narrower gender gap in tertiary enrollment, but not in secondary or primary enrollment, possibly reflecting the higher cost of tertiary education.

\section{Similarly, we find evidence for a range of possible determinants of gender gaps in labor force participation gaps:}

- Stylized facts also confirm the finding by Gonzales and others (2015) that more equal legal rights are associated with narrower labor force participation gaps (Figure 2, panel 1).

\footnotetext{
${ }^{3}$ The policy variables and gender gaps in Figure 1 and Figure 2 are all demeaned by country and by year to eliminate time and country specific effects. We demean the data by regressing all variables on year and country fixed effects.
} 
- Higher public spending on education is also associated with lower labor force participation gaps: the former is associated with lower education gaps, and more highly educated women have larger incentives to join the labor market (Figure 2, panel 2). However, the effect seems to be mainly driven by advanced economies. This may reflect that public spending on education in advanced countries provides skill sets that would make it easier for women to access the labor market.

- The impact of labor market regulation on labor force participation gaps seems to be equally ambiguous, with some relationship in advanced economies, but less so in emerging and developing economies (Figure 2, panel 3).

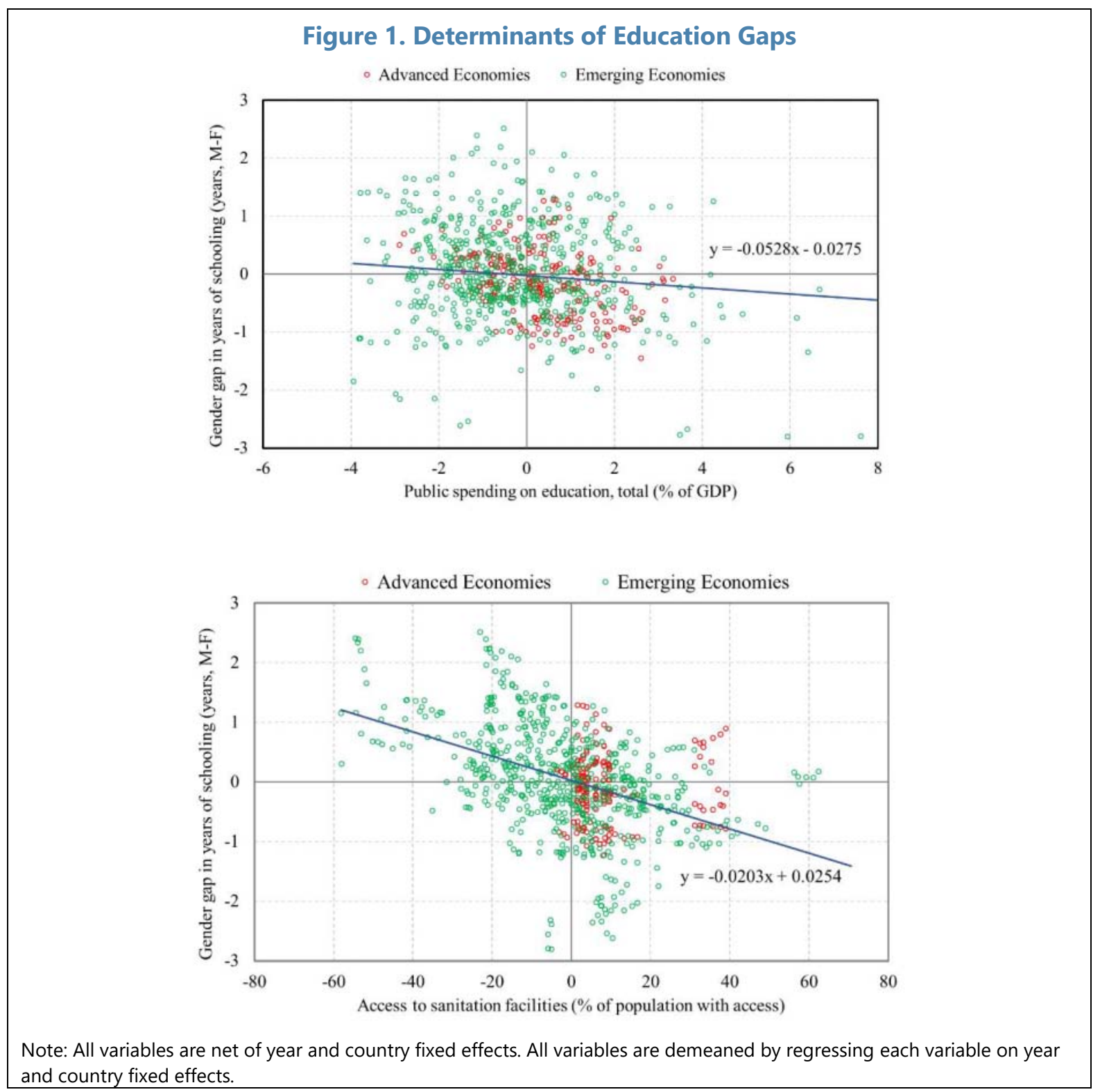


Figure 2. Determinants of Labor Force Participation Gaps
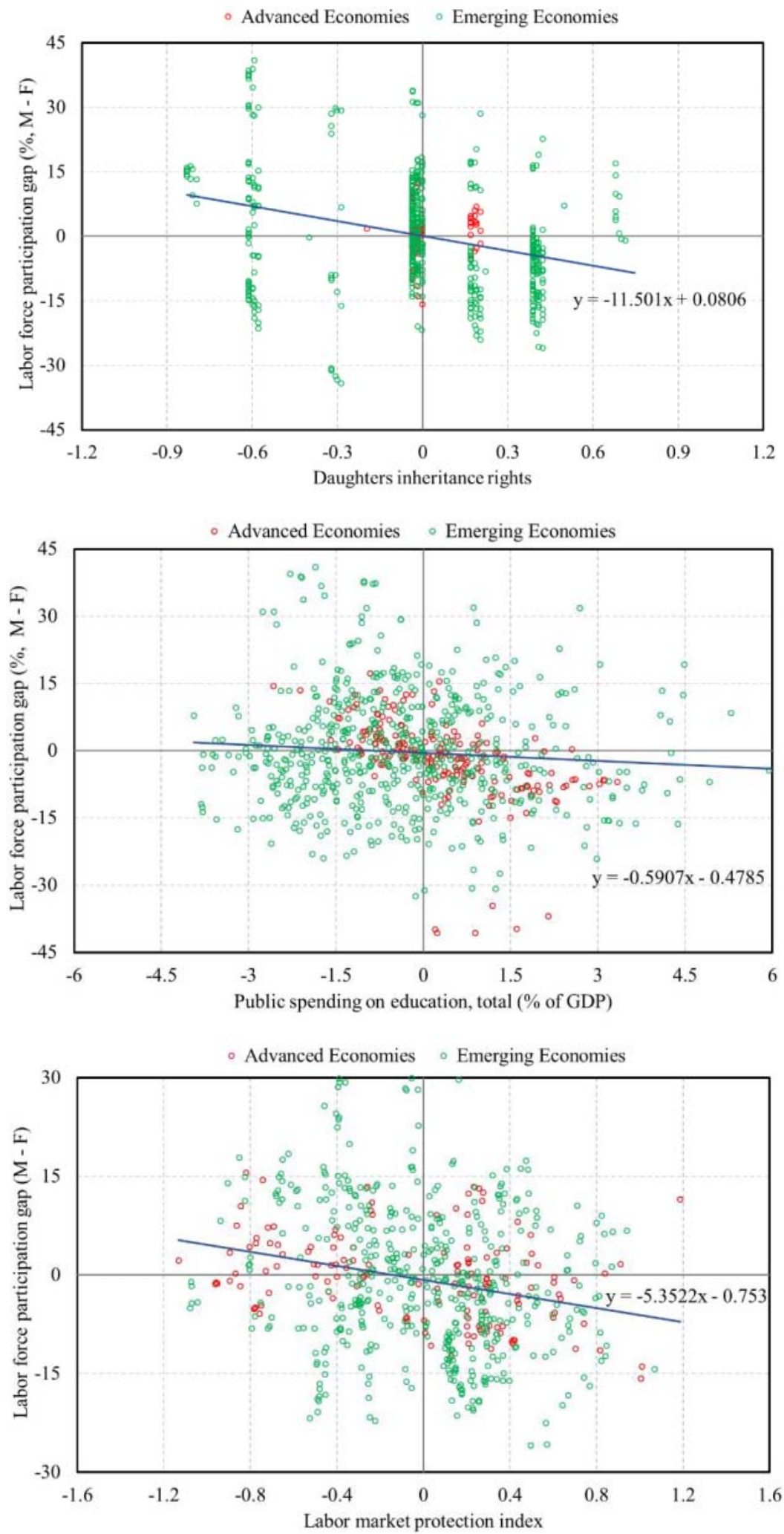

Note: All variables are net of year and country fixed effects. All variables are demeaned by regressing each variable on year and country fixed effects. 


\section{Which Factors Are Most Strongly Related to Gender IneQuality?- FREQUENTIST APPROACH}

\section{A. Empirical Specification}

\section{We estimate a fixed-effect panel regression to assess the impact of policies on} gender gaps, while controlling for country structural characteristics. ${ }^{4}$ The model allows accounting for potential unobserved non-time variant factors at the country level, and controlling for global factors which may have influenced the gaps similarly in certain points of time. Specifically, we estimate the following relationship.

In which:

$$
\operatorname{Gap}_{k, i, t}=\alpha+\delta \text { Policy }_{k, i, t}+\beta X_{k, i, t}+\mu_{k}+v_{t}+\varepsilon_{k, i, t}
$$

- $\operatorname{Gap}_{k, i, t}$ is gender gap in either labor force participation or education in county $i$ in region $k$ and in year $t$.

- Policyk,i,t $_{k}$ captures various types of policies, specifically:

Fiscal policy: public spending on education and on health, that are expected to provide both opportunities to attend school and better skills to join the labor market. It would have been desirable to also include the tax rate on secondary earners and a dummy for income vs. family taxation into the regressions to test for biases in tax incentives for women. However, these data are not available for most EMDEs.

D Several indicators of infrastructure: access to sanitation facilities, access to electricity, access to improved water source, and telephone subscription rates. Good infrastructure would decrease the time needed to spend on household activities - often disproportionately allocated to women and girls - thus freeing up their time to attend school or join the labor market. Moreover, adequate infrastructure provides a safer environment to travel to and attend school.

> Structural policies related to the labor market, the product market, public safety, and access to finance. These policies are proxied by a labor market protection index, trade openness, the political risk rating, and the control of corruption. Annex II gives an overview of the labor market protection indices examined in our analysis.

$>$ A range of legal variables to capture the equality between men and women under the law, including: equal inheritance rights for daughters and sons, women's right

\footnotetext{
${ }^{4} \mathrm{We}$ also experimented with lagged policy variables as regressors to check whether simultaneity is a concern, and the results remain largely unchanged.
} 
to head a household, and guaranteed equality of women and men before the law, from the World Bank's Women, Business and the Law database.

- $X_{k, i, t}$ is a vector of control variables chosen based on insights from the theoretical and empirical literature. They include (i) GDP per capita and its squared value to capture economic development, (ii) fertility and neonatal mortality rates, and (iii) other social factors, such as the gap in the marriage age between men and women and absolute age at marriage which determine women's educational investment decisions and time to spend in the labor market relative to men, and serve as a proxy for attitudes towards women.

- $\quad \mu_{k}$ are region fixed effects, and $v_{t}$ are year fixed effects.

19. The model is estimated initially with ordinary least squares, and then with the Bayesian Model Averaging (BMA) to check for robustness. Note that the specification does not allow us to make statements about causality; the results should rather be read as associations.

\section{B. Results}

\section{Gender Gaps in Education}

20. Countries' level of development and demographics help explain the variation of gender gaps in education across countries, and the scope for policies to narrow these gaps is large (Table 1).

- $\quad$ The relationship between gender gaps and GDP per capita is nonlinear. As noted, for example, in Golding (1995), at early stages of development, improvements in development outcomes lower the gender education gap, but they seem to increase the gap in economies at a higher development level, reflecting gaps in tertiary education. However, at higher income levels, increases in GDP per capita are associated with narrower gender gaps in tertiary education (columns (4) and (6)).

- $\quad$ Fertility and marriage gaps are closely related to gender gaps in education. Higher fertility rates at the adolescent stage are strongly associated with wider gender gaps in education, reflecting girls dropping out from school to take care of their children. A larger marriage age gap - with the average man being older than the average woman or girl at the time of marriage in most countries - is associated with larger gender gaps in education, as men on average have more time to pursue education before starting a family.

- $\quad$ A stable and safe environment, as measured by indices of political stability and public safety, links with a narrower gender gap in education.

- $\quad$ Improved access to sanitation facilities is associated with narrower gaps in years of schooling between girls and boys, as it frees time from household activity and provides a safer and more hygienic environment at schools. 
- $\quad H i g h e r$ financial development is associated with lower gender gaps in tertiary education, likely reflecting the ability to borrow to finance the higher cost of these services in many countries.

- $\quad$ Higher public spending on education and health is associated with lower gender gaps in tertiary education.

\begin{tabular}{|c|c|c|c|c|c|c|}
\hline \multicolumn{7}{|c|}{$\begin{array}{l}\text { Table 1. Determinants of the Gender Gap in Education } \\
\text { (Gender Gap in Years of Schooling, in Years, Male Minus Female) }\end{array}$} \\
\hline & $(1)$ & $(2)$ & $(3)$ & $(4)^{*}$ & $(5)$ & $(6)^{*}$ \\
\hline \multicolumn{7}{|l|}{ Stages of development } \\
\hline \multirow[t]{2}{*}{ Log (GDP per capita) } & -0.327 & $-1.635^{\star * *}$ & $-1.173^{\star * *}$ & $7.956^{\star *}$ & $-0.635^{\star}$ & $13.477^{* * *}$ \\
\hline & $(0.421)$ & $(0.313)$ & $(0.295)$ & $(3.524)$ & $(0.328)$ & $(3.687)$ \\
\hline \multirow[t]{2}{*}{ Log (GDP per capita) squared } & 0.010 & $0.091^{\star * *}$ & $0.070^{\star * \star}$ & $-0.601^{* * *}$ & $0.047^{* *}$ & $-0.971^{\star * *}$ \\
\hline & $(0.025)$ & $(0.018)$ & $(0.017)$ & $(0.223)$ & $(0.019)$ & $(0.229)$ \\
\hline \multicolumn{7}{|l|}{ Health and Demographics } \\
\hline \multirow[t]{2}{*}{ Maternal mortality ratio } & $0.001^{* * *}$ & $0.000^{* *}$ & 0.000 & $-0.010^{* * *}$ & 0.000 & -0.001 \\
\hline & $(0.000)$ & $(0.000)$ & $(0.000)$ & $(0.002)$ & $(0.000)$ & $(0.001)$ \\
\hline \multirow[t]{2}{*}{ Adolescent fertility rate } & $0.006^{* * *}$ & $0.006^{\star \star \star}$ & 0.000 & $0.056^{\star * *}$ & $0.003^{* *}$ & $0.057^{\star * \star}$ \\
\hline & $(0.001)$ & $(0.001)$ & $(0.001)$ & $(0.013)$ & $(0.001)$ & $(0.015)$ \\
\hline \multirow[t]{2}{*}{ Marriage age gap } & $0.045^{\star *}$ & $0.157^{* * *}$ & $0.158^{\star * *}$ & $0.496^{\star * *}$ & $0.084^{* * *}$ & 0.210 \\
\hline & $(0.018)$ & $(0.020)$ & $(0.020)$ & $(0.127)$ & $(0.018)$ & $(0.131)$ \\
\hline \multicolumn{7}{|l|}{ Institutions } \\
\hline \multicolumn{7}{|l|}{ Political Stability and Public } \\
\hline \multirow[t]{2}{*}{ Safety } & & $-0.123^{* * *}$ & $-0.125^{* * *}$ & $-3.440 * * *$ & $-0.058^{* *}$ & $-2.426^{* * *}$ \\
\hline & & $(0.028)$ & $(0.026)$ & $(0.345)$ & $(0.027)$ & $(0.387)$ \\
\hline \multicolumn{7}{|l|}{ Infrastructure } \\
\hline \multirow[t]{2}{*}{ Improved sanitation facilities } & & & $-0.016^{* * *}$ & -0.014 & $-0.017^{* * *}$ & 0.010 \\
\hline & & & $(0.001)$ & $(0.014)$ & $(0.002)$ & $(0.015)$ \\
\hline \multicolumn{7}{|l|}{ Financial Access } \\
\hline \multirow[t]{2}{*}{ Financial institutions access } & & & & $-8.489 * * \star$ & 0.092 & $-5.430 * \star$ \\
\hline & & & & $(2.141)$ & $(0.096)$ & $(2.317)$ \\
\hline \multicolumn{7}{|l|}{ Fiscal Policies } \\
\hline \multirow[t]{2}{*}{ Public education expenditure } & & & & & $-0.130^{* * *}$ & $-0.202^{*}$ \\
\hline & & & & & $(0.019)$ & $(0.116)$ \\
\hline \multirow[t]{2}{*}{ Public health expenditure } & & & & & 0.003 & $-1.519 * * *$ \\
\hline & & & & & $(0.017)$ & $(0.276)$ \\
\hline Region fixed effects & Yes & Yes & Yes & Yes & Yes & Yes \\
\hline Year fixed effects & Yes & Yes & Yes & Yes & Yes & Yes \\
\hline Number of Observations & 1773 & 1688 & 1656 & 1076 & 1448 & 928 \\
\hline Adjusted R-squared & 0.432 & 0.377 & 0.429 & 0.516 & 0.469 & 0.561 \\
\hline
\end{tabular}

*Note: the dependent variable in Column (4) and (6) is gender gap in tertiary school enrollment rate (male - female). 


\section{Gender Gaps in Labor Force Participation}

\section{Several factors are associated with the gender gap in labor force participation, including at the policy level (Table 2).}

- $\quad$ The results confirm the well-documented relationship between the gender gap in labor force participation and the level of development. ${ }^{5}$ At early stages of development, female labor force participation is high, since both women and men need to work for subsistence. At higher levels of GDP per capita, female labor force participation rates decrease (and the gender gap widens), reflecting trade-offs between family care and joining the labor market. Finally, female labor force participation rises again (and the gender gap narrows) when income levels move beyond a certain threshold, reflecting greater opportunities in the labor market and better services to help address family care responsibilities.

- $\quad$ Fertility and social factors are significantly related to labor force participation gaps. Mirroring the results on education gaps, higher fertility rates are strongly associated with wider gender gaps in labor force participation. Higher age gaps at marriage are also related to larger labor force participation gaps, as women's time to participate in the labor market becomes more limited relative to men. Conversely, the absolute age at marriage for women is not significantly related to the labor force participation gap. This may reflect that a young age of marriage for women may be aligned with younger marriage ages for men in some countries.

- Higher levels of education are associated with lower gender gaps in labor force participation.

- $\quad$ Stronger institutions and equality in legal rights relate to higher female labor force participation. In particular, equal inheritance rights are strongly related to lower labor force participation gaps, as is a better institutional environment, as measured by the control of corruption, and the economic risk rating of the country.

- $\quad$ Adequate infrastructure matters, and improved sanitation facilities are very strongly associated with narrower gender gaps in labor force participation. The impact of improved sanitation facilities likely arises through their effect on the time needed for household work and on security. The marginal impact of these measures, however, becomes lower at higher levels of development. Improved access to telephone lines can help provide women better access to the labor market. However, the effect is nonlinear, with men benefiting first from these improvements, while the gender gap in labor force participation only shrinks once access to telephone lines has reached a critical level, implying that the transfer of some technological improvements to women is not automatic and may require additional policies.

- $\quad$ Higher public expenditure on education is associated with narrower labor force participation gaps in advanced economies. Conversely, the impact of public expenditures on labor force participation gaps is smaller for emerging markets. This

\footnotetext{
${ }^{5}$ See, for example, Golding (1995).
} 
may reflect that gender gaps are higher in emerging markets, so that higher education expenditure may not benefit girls to the same extent as in more advanced economies.

- $\quad$ The relationship between labor market protection and labor force participation gaps is non-linear. ${ }^{6}$ At lower levels of labor market protection, an increase in the strength of protection is associated with narrower labor force participation gaps, as women seem to disproportionately benefit from stricter regulation. However, at higher levels of protection, an increase in labor market protection is associated with a widening in labor force participation gaps.

22. The results on labor market protection raise the question on whether the effect arises through higher female labor force participation or possibly lower male labor force participation. To examine these possible asymmetries for men and women, we report also the results of separate regressions of male and female labor force participation rates on all the determinants. We find that stronger labor protection laws significantly increase female labor force participation rate. There is some evidence, albeit weak, that stronger labor protection laws lower male labor force participation rate (Table 3, column 1 and 2). These findings suggest that the stronger labor protection narrows the gender gap in the labor market because better protection encourages females to participate in the labor market, whereas male workers do not benefit much from better protection. We find similar, and even stronger, effects if we regress employment to population ratio on our set of explanatory variables (Table 3, column 3 and 4). We also investigate the effects of each sub-index of labor market protection on female labor force participation. We find that among the 8 sub-indices from the World Bank Doing Business Index, maximum number of working days per week and notice period for redundancy dismissal both have a significant impact on female labor force participation (Table A2 in Annex II): A larger maximum number of working days is associated with a wider gender gap in labor force participation, whereas a longer notice period for dismissal narrows the gender gap in the labor market. These results from the subindices are consistent with our finding from the overall index that stronger protection encourages women to participate in the labor market.

\footnotetext{
${ }^{6}$ To check for robustness, alternative measures of labor market protections and sub-indices of labor market protections are used in the estimation, see Annex II for details.
} 


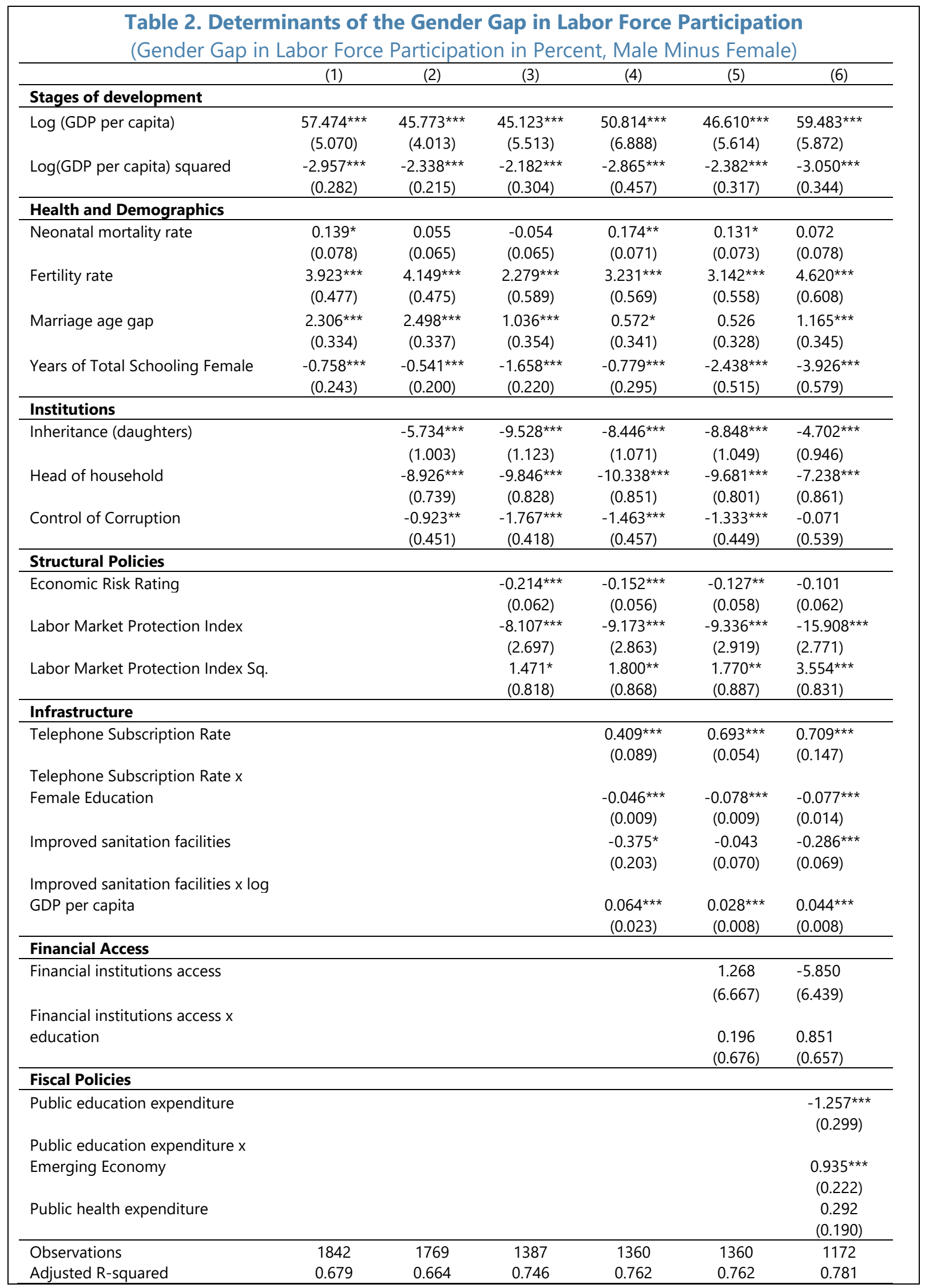


Table 3. Labor Market Protection and Labor Force Participation by Men and Women

\begin{tabular}{|c|c|c|c|c|}
\hline Dependent variable: & $\begin{array}{l}\text { Female LFP } \\
\text { rate }\end{array}$ & $\begin{array}{l}\text { Male LFP } \\
\text { rate }\end{array}$ & $\begin{array}{l}\text { Female } \\
\text { employment to } \\
\text { pop ratio }\end{array}$ & $\begin{array}{l}\text { Male } \\
\text { employment } \\
\text { to pop ratio }\end{array}$ \\
\hline & (1) & (2) & (3) & (4) \\
\hline \multicolumn{5}{|l|}{ Labor Market Protection } \\
\hline Index & $15.365^{\star \star \star}$ & -1.841 & $20.448^{* * *}$ & $4.484^{\star *}$ \\
\hline & (3.282) & (1.484) & $(3.781)$ & (1.899) \\
\hline \multicolumn{5}{|l|}{ Labor Market Protection } \\
\hline Index (squared) & $-2.961^{\star * \star}$ & $0.752^{*}$ & $-4.763^{\star \star *}$ & $-1.216^{\star \star}$ \\
\hline & $(0.976)$ & $(0.430)$ & $(1.143)$ & $(0.572)$ \\
\hline \multicolumn{5}{|l|}{ Control variables: } \\
\hline Development stage & $\checkmark$ & $\checkmark$ & $\checkmark$ & $\checkmark$ \\
\hline Health and demographics & $\checkmark$ & $\checkmark$ & $\checkmark$ & $\checkmark$ \\
\hline Institutions & $\checkmark$ & $\checkmark$ & $\checkmark$ & $\checkmark$ \\
\hline Structural policies & $\checkmark$ & $\checkmark$ & $\checkmark$ & $\checkmark$ \\
\hline Infrastructure & $\checkmark$ & $\checkmark$ & $\checkmark$ & $\checkmark$ \\
\hline Financial access & $\checkmark$ & $\checkmark$ & $\checkmark$ & $\checkmark$ \\
\hline Fiscal policies & $\checkmark$ & $\checkmark$ & $\checkmark$ & $\checkmark$ \\
\hline Region fixed effects & $\checkmark$ & $\checkmark$ & $\checkmark$ & $\checkmark$ \\
\hline Year fixed effects & $\checkmark$ & $\checkmark$ & $\checkmark$ & $\checkmark$ \\
\hline No. of Observations & 1126 & 1126 & 1126 & 1126 \\
\hline Adjusted R-squared & 0.741 & 0.507 & 0.711 & 0.586 \\
\hline
\end{tabular}

\section{IDENTIFYING ROBUST DETERMINANTS OF GENDER INEQUALITY- APPliCation OF THE BAYESIAN MODEl AVERAging APPROACH}

\section{A wide range of factors that link to gender equality has been tested in the}

literature and is confirmed in this study. However, it is still unclear to policymakers which factors are the most fundamental and robust. Mis-specified econometric models lead to biased estimates, and classical statistical approaches offers little help with model uncertainty, especially when the sample is small. Large panels, like the one we are using - covering a vast number of countries over the past three decades - alleviate the small sample issue. For policy recommendations, however, it is important to test the robustness of the determinants of gender inequality.

\section{We use Bayesian Model Averaging (BMA) to address model uncertainty and} examine the robustness of each potential determinant. BMA is a statistical technique which offers a way to think about model uncertainty (Leamer 1978; Raftery el al. 1997; Salai-Martin and others 2004). The intuition behind it is to attach probabilities to different models since it is difficult to know what the "true" model is. This requires departing from the classical statistical framework and adopt Bayesian updating. 


\section{More specifically, BMA averages across a large set of models for a given set of}

priors. ${ }^{7}$ Each model receives a weight and the final estimates are constructed as a weighted average of the parameter estimates from each of the models. The Bayesian information criterion (BIC) or the Schwarz criterion (SBIC) is used to assign a weight to each model. The weights also depend on the choice of priors specified. The general "rule of thumb" for interpreting posterior probabilities is as follows: posterior probabilities of $<50 \%, 50 \%-75 \%$ and $>95 \%$ are usually interpreted as no evidence, weak evidence and strong evidence of an effect, respectively. Following this classification, we use BMA to select the most robust determinants of gender inequality, while the level of development and its square is set to be included in all regressions as a basic control.

\section{The results highlight a smaller set of variables that is robustly related with lower} education gaps compared to the frequentist approach. ${ }^{8}$ In particular, improved sanitation facilities, higher public expenditure on education, and a lower age-gap between men and women at marriage, are all robustly associated with lower educational gaps, with a posterior inclusion probability of 100 percent.

\section{A substantial number of country characteristics and policies are robustly related to gender gaps in labor force participation.}

- Demographics. There is strong evidence of an impact of higher fertility rates and wider age gaps at marriage between men and women and wider gender gaps in the labor market, with both variables showing a posterior inclusion probability of more than 95 percent. Equal minimum ages by law for men and women could therefore help decrease the gap.

- Education. Higher levels of female education are strongly associated with lower labor force participation gaps.

- Legal rights. There is strong evidence that equal legal rights are associated with narrower gaps in labor force participation, with equal inheritance rights for daughters and sons, women's right to be head of a household entering with a posterior inclusion probability of 100 percent, and in an economically significant way.

- Infrastructure is also strongly and robustly related to lower gaps in labor force participation. In particular, improved sanitation facilities decrease the gap, in particular at early stages of development, while the impact moderates as GDP per capita increases.

Telephone subscription (landline) rates, on the other hand, are related to narrower gaps in

\footnotetext{
${ }^{7}$ A potential drawback of the BMA approach is that priors could have an impact on final estimates, and we do not have enough information to correctly specify prior distributions in most cases. However, Eicher,

Papageorgiou and Raftery (2010) show that the unit information prior used in this paper has been shown to only minimally affect estimation results.

${ }^{8}$ Note that the specification is similar to the frequentist approach and includes regional fixed effects.
} 
countries where female education is on average higher, likely because access to telephones helps carrying out jobs that require a certain level of training or education and ability to work from home or as they provide better opportunities to access digital services (to obtain information and access to finance). For instance, Ivanova, Makioka, and Wong (2017) show that access to a cellphone for all women, and access to a computer for married women is significantly related to higher female labor force participation in Costa Rica.

- Labor market protection. Stronger labor market protection is associated with lower labor force participation gaps, but the marginal impact of stronger protection declines as protection strengthens. At lower levels of labor market protection, an increase in the strength of protection is associated with narrower labor force participation gaps, as women seem to disproportionately benefit from stricter regulation. However, at higher levels of protection, an increase in protection is associated with higher gender gaps in labor force participation (see also World Bank 2013).

- Finally, there is evidence, albeit weaker than for other variables, that better control of corruption and lower economic risk are associated with a narrower gap in labor force participation, likely proxying more generally for better equality of opportunity in a country - an effective enforcement of laws, including those protecting women.

\begin{tabular}{|c|c|c|}
\hline \multicolumn{3}{|c|}{$\begin{array}{l}\text { Table 4. Gender Gap in Education: A BMA Exercise: BMA Results } \\
\text { (Gender Gap in Years of Schooling, in Years, Male Minus Female) }\end{array}$} \\
\hline & Coefficient & $\begin{array}{l}\text { Posterior } \\
\text { Inclusion } \\
\text { Probability }\end{array}$ \\
\hline log GDP per capita & -0.504 & 1.00 \\
\hline log GDP per capita squared & 0.038 & 1.00 \\
\hline Improved Sanitation Facilities & -0.017 & 1.00 \\
\hline Public Education Expenditure & -0.130 & 1.00 \\
\hline Marriage Age Gap & 0.095 & 1.00 \\
\hline Adolescent Fertility Rate & 0.001 & 0.36 \\
\hline Female Head of Household (\%) & 0.003 & 0.05 \\
\hline Maternal Mortality Ratio & 0.000 & 0.05 \\
\hline Improved Water Source & 0.000 & 0.04 \\
\hline Financial Institutions Access & 0.005 & 0.04 \\
\hline Political Risk Rating & 0.000 & 0.03 \\
\hline Trade Openness & 0.000 & 0.03 \\
\hline Daughter Inheritance Rights & 0.001 & 0.03 \\
\hline Public Health Expenditure & 0.000 & 0.03 \\
\hline $\begin{array}{l}\text { Number of countries }=120 \\
\text { Number of observations }=1468\end{array}$ & & \\
\hline
\end{tabular}


Table 5. Determinant of Gender Gap in Labor Force Participation: BMA Results (Gender Gap in Labor Force Participation in Percent, Male Minus Female)

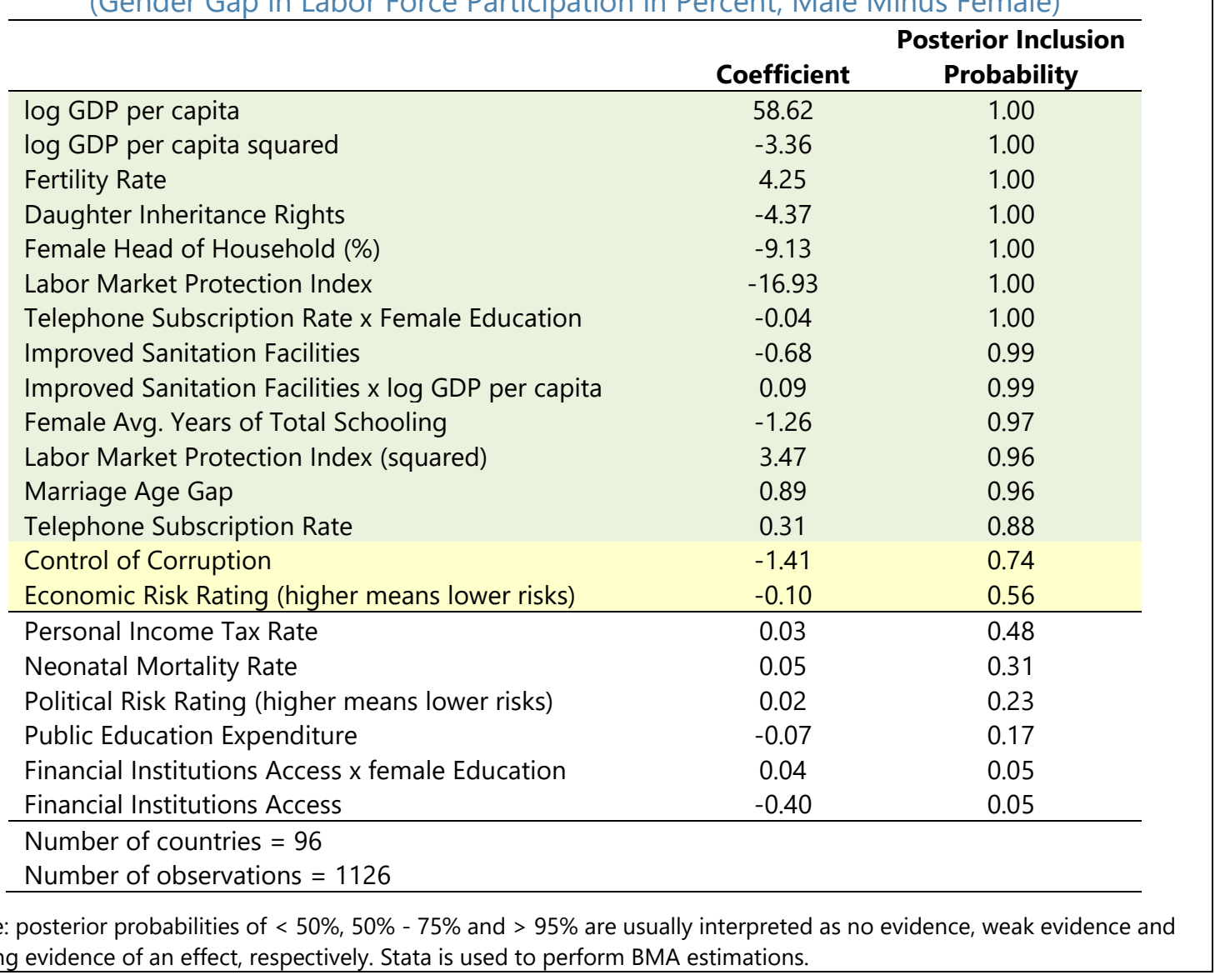

\section{Quantifying the Effect of Policies Across Regions}

28. This section uses the above empirical results to quantify the main policy and structural constraints to female labor force participation across regions in 2005-2010. In particular, we use previously derived coefficients obtained from the BMA analysis and regional averages over a five-year period to decompose the male-to-female labor force participation gap into the impact from:

- $\quad$ policies, i.e. institutions, structural policies, infrastructure, and fiscal expenditure;

- demographics and health outcomes, such as the neonatal mortality rate, the fertility rate and the marriage age gap; and

- region-specific factors (region FE) and the level of development.

29. The results highlight that policies have contributed to a lower labor force participation gap in all regions, but to a different extent. Figure 3 plots the determinants of the labor force participation gap for all regions, highlighting that: 
- Demographics and health outcomes have widened the labor force participation gap in all regions. The gap has been widened by these two factors by as much as 33 percentage points in subSaharan Africa, with much smaller effects in North America and Europe and Central Asia (about 10 percentage points). Within demographics, fertility has had the largest impact throughout, in particular in sub-Saharan Africa (+241/2 percentage points). The widening of the gap due to the marriage age gap has also been substantial, reaching from about $2 \frac{1}{2}$ percentage points in North America to about 6 percentage points in sub-Saharan Africa and South Asia.

- Policies have narrowed the gap in all regions but with significant variations. While policies accounted for an about 45-49 percentage points lower labor force participation gaps in sub-Saharan Africa, MENA and South Asia, they play a greater role in North America and help lower it by 66 percentage points.

Regional effects (comparing to North America as the base region), that could capture attitudes and social norms but also other unobserved characteristics, have widened the gender gap in MENA, Latin America and the Caribbean, East Asia and Pacific, and South Asia, but lowered the gap in sub-Saharan Africa.

\section{The large impact of policies begs the question which policies have yielded the biggest bang for the buck in each region (Figure 4).}

- Educating girls has paid off in all regions, with some having a large potential to catch up. Education, as measured by the average years of female total schooling, has narrowed the gap by as much as 47 percentage points in North America, more than 41 percentage points in Europe and in Central Asia, and more than 35 percentage points in East Asia and the Pacific. In other regions, the potential to lower gaps in labor force participation is still high (South Asia, sub-Saharan Africa) (panel 1). 
- Institutions, including legal rights, have also had a large impact and contributed more than 10 percentage points to the narrowing of the gap in all regions except MENA as this regions till faces a relatively high number of legal restrictions against women (panel 2).

- Infrastructure, in particular enhancing sanitation facilities, can play a large role at lower levels of development, with strong potential to catch up in South Asia and sub-Saharan Africa (panel 3).

- Expenditures on health and education have a direct and negative impact on the labor force participation gap. Further, they would influence the gap indirectly through better educational outcomes (panel 4).

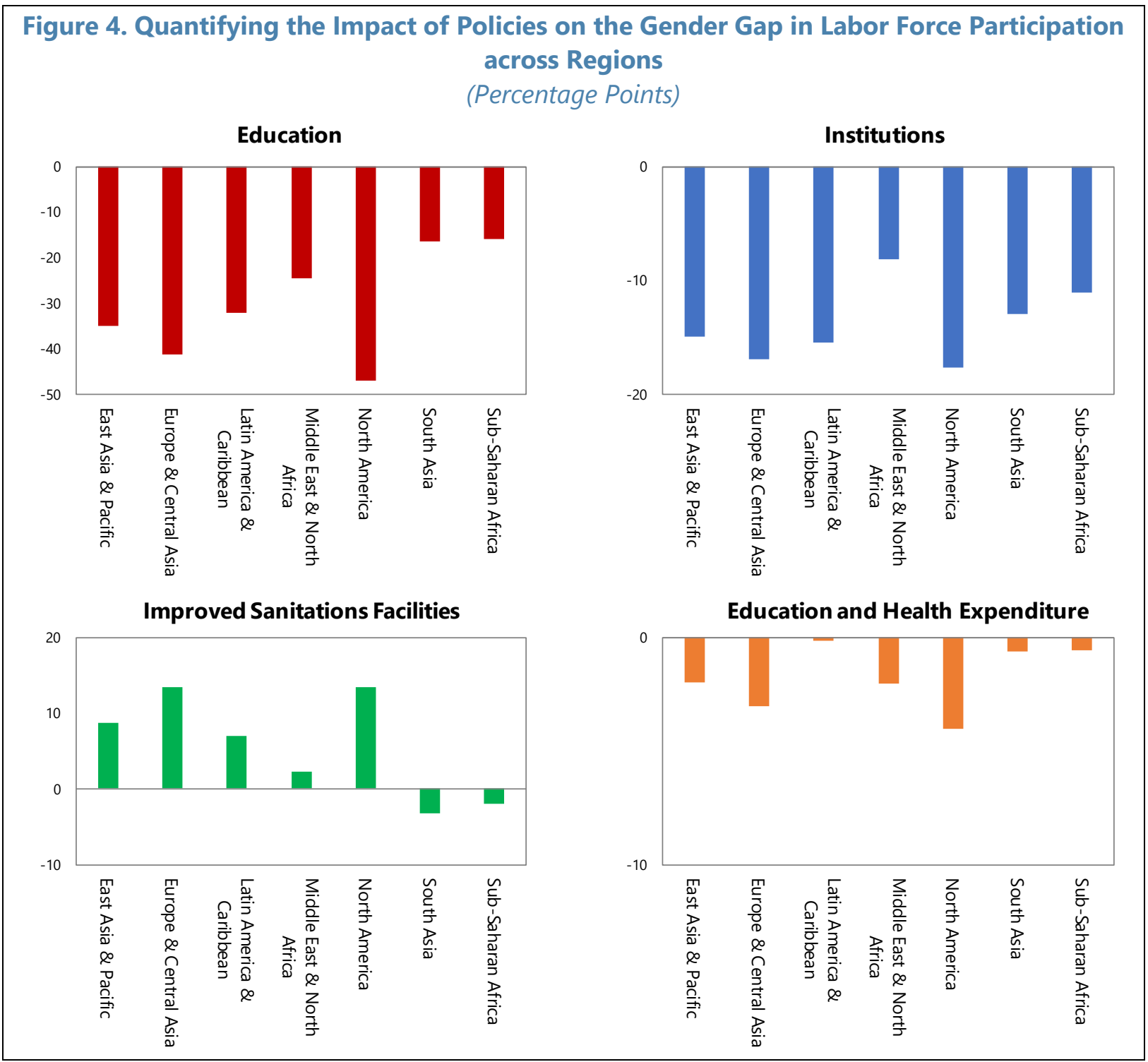




\section{CONCLUSIONS ANd Policy IMPlications}

\section{The novel contribution of this paper is the identification of the most important and robust determinants of gender inequality, thus providing a more useful guide for policy action. We complement the existing literature by explicitly addressing model uncertainty that is inherent in all empirical estimations where the proposed set of potential determinants is large. In fact, in addition to standard fixed-effects estimations for a large panel, our paper is the first to apply Bayesian Model Averaging - a methodology that is specifically designed to highlight factors that are robustly related to a variable of interest - to the literature on gender gaps in education and labor force participation. With that, our paper is able to highlight policy areas that are likely to yield the biggest bang for the buck.}

\section{The paper finds that some policies are closely linked to gender equality.}

- Education gaps. Good sanitation facilities contribute to narrow gender education gaps by freeing up time from household activity and providing a safer environment at school. Low adolescent fertility and small marriage age gap prolong the time in which girls do not face the trade-off between family responsibilities and education and are associated with lower gender gaps in education. The result that adequate sanitation facilities and narrower marriage age gaps are associated with a lower gender gap in education is robust across many different model specifications. In addition, a stable and safe environment, as measured by indices of political stability and public safety, is also associated with a narrower education gap between males and females. Higher financial development links with lower gender gaps in tertiary education, likely reflecting the higher cost of these services in many countries. Higher public spending on education and health is associated with narrower gender gaps in tertiary education.

- Labor force participation gaps. Adequate infrastructure is strongly associated with lower gender gaps in labor force participation; this is particularly true for improved sanitation facilities. Stronger legal rights for females, low adolescent fertility, a small marriage age gap are also factors that go hand in hand with narrower gender gaps. The relationship between labor market protection and gender gaps in the labor market is non-linear. At lower levels of labor market protection, stronger protection is associated with lower labor force participation gaps, but at higher levels of protection, and increase in protection is associated with higher gender gaps in labor force participation. All these factors are robustly related to gender gaps in labor force participation. Finally, higher public expenditure on education is associated with narrower labor force participation gaps in advanced economies, and there is some evidence that a stronger institutional environment - as measured by better control of corruption and lower economic riskboost female labor force participation.

33. What types of economic policies can then boost gender equality? First of all, educating girls has paid off in all regions, with a large potential of increasing female education further in sub-Saharan Africa and South Asia. Fiscal policies aiming at improving infrastructure, especially sanitation facilities in low-income countries also matter. Moreover, social campaigns and policies to cut adolescent fertility and narrow the marriage age gap will 
foster both girls' education and lower the labor force participation gap directly and indirectly. Labor market policies can also support gender equality. However, our results suggest that strengthening job protection can help narrow the labor force participation gaps only in institutional settings where job protection is low. Instead, making the labor market too rigid could widen the labor force participation gap. 


\section{References}

Adukia, A., 2017, Sanitation and Education. American Economic Journal: Applied Economics, 9(2), pp.23-59.

Aguirre, D., L. Hoteit, et al., 2012, Empowering the Third Billion: Women and the World of Work in 2012. New York: Booz \& Co.

Barro, R.J. and J.W. Lee, 2013, A New Data Set of Educational Attainment in the World, 1950-2010. Journal of development Economics, 104, pp.184-198.

Becker, G.S., 1965, A Theory of the Allocation of Time. The Economic Journal, pp. 493517.

Bloom, E., D. Canning, G. Fink, and J.E. Finlay, 2009, Fertility, Female Labor Force Participation, and the Demographic Dividend. Journal of Economic Growth 14 (2): 79101.

Botero, J.C., S. Djankov, R. La Porta, F. Lopez-de-Silanes, and A. Shleifer, 2004, The Regulation of Labor. The Quarterly Journal of Economics, 119(4), pp.1339-1382.

Breunig, R., X. Gong and A. King, 2012. Partnered Women's Labour Supply and Child-Care Costs in Australia: Measurement Error and the Child-Care Price. Economic Record, 88(s1), pp.51-69.

Campos, N.F. and J.B. Nugent, 2012, The Dynamics of the Regulation of Labor in Developing and Developed Countries since 1960. Unpublished.

Cuberes, D. and M. Teignier, 2016, Aggregate effects of gender gaps in the labor market: A quantitative estimate. Journal of Human Capital, 10(1), pp.1-32.

Das, S., S. Jain-Chandra, M.K. Kochhar, and N. Kumar, 2015, Women Workers in India: Why so Few Among So Many? IMF Working Paper 15/55.

De Laat, J. and A. Sevilla-Sanz, 2011, The Fertility and Women's Labor Force Participation Puzzle in OECD Countries: The Role of Men's Home Production. Feminist Economics 17(2): 87-119.

Du, Q., S.J. Wei, and P. Xie, 2013, Roads and the Real Exchange Rate. National Bureau of Economic Research, No. w19291.

Duflo, E., 2012, Women Empowerment and Economic Development. Journal of Economic Literature, 50(4), pp.1051-1079.

Durlauf, S.N., Johnson, P.A., Temple, J.R. 2005. “Chapter 8 Growth Econometrics. Handbook of Economic Growth" 1 (1), 555-677. 
Eckstein, Z. and O. Lifshitz, 2011, Dynamic Female Labor Supply. Econometrica, 79(6), pp.1675-1726.

Eckstein, Z. and K.I. Wolpin, 1989, Dynamic Labour Force Participation of Married Women and Endogenous Work Experience. The Review of Economic Studies, 56(3), pp.375390 .

Eicher, T.S., C. Papageorgiou and A.E., Raftery, 2011, Default priors and predictive performance in Bayesian model averaging, with application to growth determinants. Journal of Applied Econometrics, 26(1), pp. 30-55.

Eicher, T.S., and M. Newiak, 2013, "Intellectual Property Rights as Development Determinants," Canadian Journal of Economics. Volume 46, issue 1, pp. 4-22.

Elborgh-Woytek, K., M. Newiak, K. Kochhar, S. Fabrizio, R. Kpodar, P. Wingender, B. Clements, and G. Schwartz, 2013, Women, Work, and the Economy: Macroeconomic Gains from Gender Equity. Staff Discussion Note, SDN/13/10, International Monetary Fund.

Fernandez, C., E. Ley, and M.F.J. Steel, 2001, "Model Uncertainty in Cross-Country Growth Regressions," Journal of Applied Econometrics 16, 563-76

Fernández, R. and J.C. Wong, 2014, Divorce Risk, Wages and Working Wives: A Quantitative Life-Cycle Analysis of Female Labour Force Participation. The Economic Journal, 124(576), pp. 319-358.

Field, E. and A. Ambrus, 2008, Early Marriage, Age of Menarche, and Female Schooling Attainment in Bangladesh. Journal of political Economy, 116(5), pp.881-930.

Ghani, E., W.R. Kerr and S.D. O'Connell, 2013, Local Industrial Structures and Female Entrepreneurship in India. Journal of Economic Geography, 13(6), pp. 929-964.

Goldin, Claudia (1995) "The U-Shaped Female Labor Force Function in Economic Development and Economic History" in T. Paul Shultz Investment in Women's Human Capital and Economic Development, University of Chicago Press, pp. 61-90.

Gonzales, M.C., S. Jain-Chandra, M.K. Kochhar and M.M. Newiak, 2015, Fair Play: More Equal Laws Boost Female Labor Force Participation, Staff Discussion Notes No. 15/2, International Monetary Fund.

Hannan, C. and I. Andersson, 2002, Gender Perspectives on Ecological Sanitation. Stockholm, Ecosanres.

Heckman, J.J. and T. MaCurdy, 1982, Corrigendum on a Life cycle Model of Female Labour Supply. The Review of Economic Studies, 49(4), pp. 659-660. 
Ivanova, A., R. Makioka and J. Wong, 2017, "Costa Rica”. In: Women Work, and Economic Growth-Leveling the Playing Field. Washington: International Monetary Fund.

Jayachandran, S., 2015, The Roots of Gender Inequality in Developing Countries. Annual Review of Economics. Vol. 7: 63-88.

Jones, G. and W.J. Schneider, 2006, Intelligence, Human Capital, and Economic Growth: A Bayesian Averaging of Classical Estimates (BACE) Approach. Journal of Economic Growth, 11(1), pp. 71-93.

Kalb, G., 2009, Children, Labour Supply and Child Care: Challenges for Empirical Analysis. Australian Economic Review, Vol. 42, No. 3: pp. 276-99.

Kochhar, M.K., S. Jain-Chandra and M.M. Newiak, 2017, Women, Work, and Economic Growth : Leveling the Playing Field, International Monetary Fund.

Lamb, J., 2015, The Role of Water in Addressing Gender Inequality, in Water for Women p. 7, Water Aid.

Leamer, E.E., 1978, Specification Searches: Ad hoc Inference with Nonexperimental Data (Vol. 53). John Wiley \& Sons Incorporated.

Luo, P., 2018, The Other Gender Gap: Female Entrepreneurship after WWII. Working Paper, Harvard University.

Masanjala, W.H. and C. Papageorgiou, 2008, Rough and Lonely Road to Prosperity: A Reexamination of the Sources of Growth in Africa using Bayesian Model Averaging. Journal of Applied Econometrics, 23(5), pp.671-682.

Mishra, V. and R. Smyth, 2010, Female Labor Force Participation and Total Fertility Rates in the OECD: New Evidence from Panel Cointegration and Granger Causality Testing. Journal of Economics and Business, 62(1), pp. 48-64.

Moral-Benito, E., 2012, Determinants of Economic Growth: a Bayesian Panel Data Approach. Review of Economics and Statistics, 94(2), pp. 566-579.

Moral-Benito, E., 2015, Model Averaging in Economics: An Overview. Journal of Economic Surveys, 29(1), pp. 46-75.

Norando, G.C., 2010, Essays on Infrastructure, Female Labor Force Participation and Economic Development. University of Iowa, Iowa Research Online.

Raftery, A.E., D. Madigan, and J.A. Hoeting, 1997, Bayesian Model Averaging for Linear Regression Models. Journal of the American Statistical Association, March 1997, 92(437), pp. 179-91. 
Revenga, A. and S. Shetty, 2012. World Development Report on Gender Equality and Development. World Bank.

Sala-i-Martin, X., G. Doppelhofer, and R. I. Miller, 2004, Determinants of Long-Term Growth: A Bayesian Averaging of Classical Estimates (BACE) Approach. The American Economic Review, 94(4), pp. 813-835.

Sen, A., 2001, The Many Faces of Gender Inequality. New Republic, pp. 35-39.

Stimple, A., and D. Stadelmann, 2016, "Marriage Age Affects Educational Gender Inequality: International Evidence. CREMA Working Paper No. 2016-02.

Thévenon, O., 2013, Drivers of Female Labour Force Participation in the OECD.

Tsangarides, C.G., 2004, A Bayesian Approach to Model Uncertainty. IMF Working Paper $04 / 68$.

UNESCO, 2014, Good Policy and Practice in Health Education. Puberty Education and Menstrual Hygiene Management. Booklet 9. United Nations Educational, Scientific and Cultural Organization.

World Bank, 2012, World Development Report 2013: Jobs. World Development Report. Washington, D.C.: World Bank. 


\section{ANNEX I. DATA}

We construct a comprehensive cross-country dataset of economic, political, institutional, and social variables for the period 1980-2014. We collect data from various sources including the World Development Indicators, Women, Business and the Law, IMF Fiscal Affairs, IMF WEO, United Nations, International Labor Organization, Polity, International Country Risk Guide, Barro-Lee (2013), Botero and others (2004), and Campos and Nugent (2012). Since the task of this paper is to draw lessons across countries and over time, we carefully select the most standard and widely accepted data source for each policy variable to maximize comparability across countries. Please refer to Table A1 below for summary statistics and data sources of all the policy variables that we focus on in this paper.

\begin{tabular}{|c|c|c|c|c|c|c|c|}
\hline \multirow{3}{*}{ Variable Names } & \multicolumn{6}{|c|}{ Table A1. Summary Statistics } & \multirow{3}{*}{ Data Source } \\
\hline & \multicolumn{3}{|c|}{ Advanced Markets } & \multicolumn{3}{|c|}{ Emerging and Developing Markets } & \\
\hline & No. of Obs & Mean & Std. Dev & No. of Obs & Mean & Std. Dev & \\
\hline \multicolumn{8}{|l|}{ Gender Gaps } \\
\hline Labor Force Participation Gap (M - F) & 792 & 17.0 & 9.0 & 3408 & 25.7 & 18.2 & World Bank, WDI \\
\hline Literacy Gap (M - F) & 248 & 3.5 & 4.1 & 2924 & 10.4 & 10.3 & World Bank, WDI \\
\hline Primary School Enrollment Gap (M - F) & 1256 & 0.5 & 1.8 & 5513 & 8.8 & 12.4 & World Bank, WDI \\
\hline Secondary School Enrollment Gap (M - F) & 1218 & -0.6 & 6.8 & 5138 & 3.1 & 9.8 & World Bank, WDI \\
\hline Tertiary School Enrollment Gap (M - F) & 1238 & -2.8 & 13.3 & 4323 & -1.0 & 8.0 & World Bank, WDI \\
\hline Years of Schooling Gap & 1683 & -3.3 & 6.9 & 5559 & 5.2 & 9.0 & Barro and Lee (2013) \\
\hline \multicolumn{8}{|l|}{ Access to Finance } \\
\hline Financial Institutions Access & 1122 & 0.4 & 0.4 & 4828 & 0.1 & 0.2 & World Bank, FINDEX \\
\hline \multicolumn{8}{|l|}{ Institutions } \\
\hline Daughter Inheritance Rights & 1872 & 1.0 & 0.1 & 8117 & 0.7 & 0.5 & World Bank, WBL \\
\hline Female Head of Household & 1872 & 0.9 & 0.2 & 8117 & 0.7 & 0.5 & World Bank, WBL \\
\hline Guaranteed Equality by Law & 3079 & 0.9 & 0.3 & & & & World Bank, WBL \\
\hline Political Risk Rating & 984 & 80.7 & 8.9 & 3896 & 57.3 & 11.6 & ICRG \\
\hline Government Effectiveness & 627 & 1.5 & 0.5 & 2837 & -0.4 & 0.7 & World Bank, WGI \\
\hline Regulatory Quality & 627 & 1.4 & 0.4 & 2839 & -0.4 & 0.7 & World Bank, WGI \\
\hline Rule of Law & 646 & 1.4 & 0.5 & 2877 & -0.4 & 0.7 & World Bank, WGI \\
\hline Control of Corruption & 627 & 1.5 & 0.7 & 2839 & -0.4 & 0.7 & World Bank, WGI \\
\hline \multicolumn{8}{|l|}{ Demographics } \\
\hline Female Avg. Years of Total Schooling & 4402 & 6.5 & 3.2 & & & & World Bank, DHS \\
\hline Contraceptive Prevalence & 628 & 72.9 & 9.0 & 3284 & 39.9 & 21.5 & World Bank, WDI \\
\hline Maternal Mortality Ratio & 768 & 9.7 & 5.8 & 3480 & 297.1 & 357.8 & World Bank, WDI \\
\hline Adolescent Fertility Rate & 637 & 16.8 & 10.5 & 1996 & 78.9 & 29.5 & United Nations \\
\hline Marriage Age Gap & 1215 & 2.7 & 0.7 & 4368 & 4.2 & 1.8 & United Nations \\
\hline \multicolumn{8}{|l|}{ Infrastructure } \\
\hline Telephone Subscription Rate & 1783 & 34.7 & 18.1 & 7141 & 6.6 & 9.2 & World Bank, WDI \\
\hline Access to Electricity & 714 & 98.7 & 5.4 & 3192 & 65.3 & 33.4 & World Bank, WDI \\
\hline Improved Water Source & 735 & 99.6 & 1.2 & 3328 & 79.6 & 18.8 & World Bank, WDI \\
\hline Improved Sanitation Facilities & 690 & 99.6 & 1.1 & 3276 & 60.8 & 30.6 & World Bank, WDI \\
\hline \multicolumn{8}{|l|}{ Fiscal Policies } \\
\hline Public Education Expenditure & 961 & 5.0 & 1.3 & 2829 & 4.4 & 2.7 & World Bank, WDI \\
\hline Public Health Expenditure & 594 & 6.1 & 1.7 & 2635 & 3.2 & 2.1 & World Bank, WDI \\
\hline \multicolumn{8}{|l|}{$\underline{\text { Structural Policies }}$} \\
\hline Employment Protection Index & 1062 & 1.5 & 0.7 & 3571 & 1.6 & 0.4 & Campos and Nugent (2012) \\
\hline Trade Openness & 1075 & 95.0 & 76.2 & 4718 & 79.3 & 45.7 & IMF, WEO \\
\hline
\end{tabular}




\section{AnNex II. LABOR Market Protection IndeX}

We use three labor market protection indices to examine the role of employment protection on female labor force participation. We first use the Employment Protection Legislation Index developed in Campos and Nugent (2012) in our baseline results. The index consists of the following four components:

1. Conditions of work (hours of work, weekly rest and paid leave)

2. Employment security termination of employment

3. Conditions of employment (labor contracts, wages and personnel management)

4. General provisions (labor codes, general labor and employment acts)

We use two other labor market protection indices to check the robustness of our results. We use the Employment Laws Index developed in a seminal paper by Botero, Djankov, La Porta, Lopez de Silanes and Shleifer (QJE 2004). We also use the World Bank Doing Business Index and its sub-indices (Table A2), which adopts the BDLLS methodology and extends to a larger set of countries and to more recent years. The index consists of the following four components:

1. Cost of increasing hours worked

2. Cost of firing workers

3. Dismissal procedures

4. Alternative employment contracts

\begin{tabular}{|c|c|c|c|c|c|c|c|c|}
\hline Dependent variable: gender gap in labor force participation & (1) & (2) & (3) & (4) & (5) & (6) & (7) & (8) \\
\hline Can the workweek for a single worker extend to 50 hours per week & $\begin{array}{l}-5.56 \\
(4.78)\end{array}$ & & & & & & & \\
\hline Are there restrictions on night work & & $\begin{array}{c}3.60 \\
(2.78)\end{array}$ & & & & & & \\
\hline Are there restrictions on "weekly holiday" work & & & $\begin{array}{l}-2.92 \\
(2.86)\end{array}$ & & & & & \\
\hline What is the maximum number of working days per week & & & & $\begin{array}{c}8.01^{* * *} \\
(2.73)\end{array}$ & & & & \\
\hline Any retraining or reassignment obligation before making a worker redundant & & & & & $\begin{array}{l}-4.04 \\
(3.12)\end{array}$ & & & \\
\hline Any priority rules that apply to redundancy dismissals or lay-offs & & & & & & $\begin{array}{l}-3.87^{*} \\
(2.30)\end{array}$ & & \\
\hline Notice period for redundancy dismissal after $20 \mathrm{yrs}$ of employment & & & & & & & $\begin{array}{c}-0.54^{* * *} \\
(0.18)\end{array}$ & \\
\hline Severance pay for redundancy dismissal after 20 yrs of employment & & & & & & & & $\begin{array}{r}0.045 \\
(0.031 \\
\end{array}$ \\
\hline No. Observations & 121 & 121 & 121 & 120 & 120 & 120 & 120 & 120 \\
\hline Adjusted R-squared & 0.437 & 0.435 & 0.433 & 0.458 & 0.439 & 0.441 & 0.464 & 0.441 \\
\hline
\end{tabular}

